\title{
30 years of data reveal dramatic increase in abundance of brown trout following the removal of a small hydrodam
}

Birnie-Gauvin, Kim; Larsen, Martin Hage; Nielsen, Jan; Aarestrup, Kim

Published in:

Journal of Environmental Management

Link to article, DOI:

10.1016/j.jenvman.2017.09.022

Publication date:

2017

Document Version

Peer reviewed version

Link back to DTU Orbit

Citation (APA):

Birnie-Gauvin, K., Larsen, M. H., Nielsen, J., \& Aarestrup, K. (2017). 30 years of data reveal dramatic increase in abundance of brown trout following the removal of a small hydrodam. Journal of Environmental Management, 204, 467-471. https://doi.org/10.1016/j.jenvman.2017.09.022

\section{General rights}

Copyright and moral rights for the publications made accessible in the public portal are retained by the authors and/or other copyright owners and it is a condition of accessing publications that users recognise and abide by the legal requirements associated with these rights.

- Users may download and print one copy of any publication from the public portal for the purpose of private study or research.

- You may not further distribute the material or use it for any profit-making activity or commercial gain

- You may freely distribute the URL identifying the publication in the public portal 
230 years of data reveal dramatic increase in abundance of brown trout following the removal of a

4

6

7

8

9

10

11

12

13

14

16

17

18

19

20

21

22

23

\section{1}

\section{small hydrodam}

Accepted in Journal of Environmental Management

(n)

Kim Birnie-Gauvin ${ }^{1}$, Martin H. Larsen ${ }^{1,2}$, Jan Nielsen $^{1}$, Kim Aarestrup ${ }^{1}$

8

(n)

0

$1{ }^{1}$ DTU Aqua, Section for Freshwater Fisheries and Ecology, Vejlsøvej 39, 8600 Silkeborg

${ }^{2}$ Danish Centre for Wild Salmon, Brusgårdsvej 15, 8960 Randers, Denmark

5 Author for correspondence: K. Birnie-Gauvin, kbir@ aqua.dtu.dk

\section{Running head: Dam removal increases trout density}




\section{Abstract}

25 Humans and freshwater ecosystems have a long history of cohabitation. Today, nearly all major rivers

26 of the world have an in-stream structure which changes water flow, substrate composition, vegetation, and fish assemblage composition. The realization of these effects and their subsequent impacts on population sustainability and conservation has led to a collective effort aimed to find ways to mitigate these impacts. Barrier removal has recently received greater interest as a potential solution to restore river connectivity, and reestablish high quality habitats, suitable for feeding, refuge and spawning of fish. In the present study, we present thirty years of data from electrofishing surveys obtained at two sites, both prior to and following the removal of a small-scale hydropower dam in Central Jutland, Denmark. We demonstrate that the dam removal has led to a dramatic increase in trout density, especially in young of the year. Surprisingly, we found that this increase was not just upstream of the barrier, where the ponded zone previously was, but also downstream of the barrier, despite little changes in habitat in that area. These findings suggest that barrier removal may be the soundest conservation option to reinstate fish population productivity.

Keywords: conservation, dams, fish passage, migration, population, Salmonidae

\section{Abbreviations: $\quad$ YOY - young of the year}

OLD - older fish 


\section{Introduction}

48 Obstacles within watercourses, such as dams and weirs, have become pervasive in today's freshwater ecosystems. Beginning in the tenth century, humans have modified rivers to operate mills, net fish as a food source, navigate to trade with foreign countries, generate energy and regulate water (Baxter 1977; Dudgeon 1992; Northcote 1998; Downward and Skinner 2005; Nützmann et al. 2011). Today, scarcely any river systems remain unaltered by anthropogenic structures (Morita and Yamamoto 2001; Hall et al. 2011).

The impacts that dams have had on freshwater ecosystems are considerable; alterations to the physical and chemical characteristics of the water and surrounding landscapes has resulted in the increase of homogeneity and a decrease in suitable habitat for many species, including the loss of lowwater spawning and nursery habitats for salmonids and lampreys in ponded zones (Baxter 1977; Jungwirth et al. 2000; Birnie-Gauvin et al. in press); and interference with one or more stage in the life cycle of many fish species has led to changes in fish assemblages (Lucas and Baras 2001). For example, brown trout (Salmo trutta) and Atlantic salmon (S. salar) smolts showed significant delays and increased mortality when released upstream of a small weir in comparison to individuals released downstream of the barrier (Aarestrup and Koed 2003). Furthermore, the natural flow patterns of regulated rivers, which provide important cues for fish migrations, have been altered extensively, thereby also reducing biodiversity (Bunn and Arthington 2002). This reduction in biodiversity and population numbers is further exacerbated by an increased mortality of migratory fish in reservoirs (or ponded zones) formed by dams (Jepsen et al. 1998). Fish will often accumulate in these ponded zones, as well as just downstream of a dam (Koed et al. 2002), making them more susceptible to predation by other fish and to exploitation by fisheries (Poe et al. 1991; Lucas and Baras 2001). Taken together, the construction of dams and weirs is estimated to account for 55 to $60 \%$ of the known causes leading to 
70 freshwater fish endangerment (Northcote 1998). To aggravate their status, freshwater species are

71 already considered more imperiled than terrestrial species (McAllister et al. 1997; Ricciardi and

72 Rasmussen 1999), requiring us to take action.

73 The recognition of the negative impacts of barriers in the last few decades has led to the quest

74 for solutions that would enable safe passage. For example, many hydrodams in the United States have

75 adopted the policy of manually trapping and moving fish passed dams (Cada 1998). In other cases, fish

76 passes, such as fish ladders, fish elevators or nature-like fish passes, have been implemented (see

77 Jungwirth et al. 1998 for review). Despite these efforts however, the efficiency of fish passage facilities

78 remains underwhelming in many cases. In the River Gudenaa, Denmark, the Tangeværket Dam has

79 resulted in the extinction of Atlantic salmon and the near-elimination of upstream migrating sea trout

80 (S. trutta), despite the presence of a fish ladder (Aarestrup and Jepsen 1998).

Though larger obstacles are viewed as having more significant consequences, smaller barriers

82

83

84

85

86

87

such as weirs are more common (estimated two- to four-fold; Lucas et al. 2009). On a large scale, their cumulative effects are likely to be significant (Cooke et al. 2005), though these low-head barriers continue to be less studied (Lucas and Baras 2001). No matter the barrier size however, barrier removal is presumably the most appropriate solution (Cowx and Welcomme 1998). It (1) restores longitudinal connectivity, (2) restores the natural habitat (including physical and chemical properties), and (3) enables safe fish passage. Despite the recognition that removal is likely the soundest of all conservation options since 1998 (by Cowx and Welcomme), relatively few studies have examined the consequences of barrier removal (but see Bednarek 2001 for review on ecological effects), especially in the context of smaller obstacles and over long timescales. The recovery response of fish populations and communities to removal remains largely undocumented (Doyle et al. 2005) making it difficult to make predictions and influence decisions made at the management level. Existing recommendations include viewing 

and nursery areas of River Gudenaa, migrate down to the lake to feed, and return to the river to spawn.

small barrier removals as opportunities to educate ourselves on the impacts before contemplating large barrier removals, which are likely accompanied by greater consequences (Doyle et al. 2003). The few studies that have examined the effects of barrier removal on fish assemblage and distributions have been carried over relatively short periods of time, but all indicated or predicted positive impacts of removal on native species (e.g., Catalano et al. 2007; Pess et al. 2008; Burroughs et al. 2010; Hitt et al. 2012). Here, we present 30 years of data on brown trout numbers both before and after the removal of a small hydropower dam (Vilholt, Central Jutland, Denmark). Such temporal data on the subject has never been available prior to this study (that we know of), making it the first of its kind.

\section{Methods}

\section{Study site}

River Gudenaa is one of the largest rivers in Jutland, Denmark, running for approximately $149 \mathrm{~km}$ before entering the Randers Fjord. In 1866, the Vilholt hydropower dam (Vilholt Mølle) was established in River Gudenaa (Figure 1). Since 1987, the local authorities (Vejle County and Horsens Municipality), along with the National Forest and Nature Agency, had debated with stakeholders for the removal of the Vilholt dam to restore natural conditions and faunapassage in the river. The dam was finally removed in 2008 after nearly two decades of debate. Lake Moss $\varnothing$ is located approximately $6.5 \mathrm{~km}$ downstream of where the dam used to be. The river system is now home to a large population of brown trout (S. trutta), with Lake Mossø serving as highly productive feeding grounds for lakedwelling brown trout (herein referred to as lake trout). These lake trout originate from the spawning

\section{Electrofishing surveys}


116 Starting in 1997 through 2016, electrofishing surveys were conducted (end of August to beginning of

117 October) $1.5 \mathrm{~km}$ upstream of the dam within the ponded zone (Figure 1, A). Prior to removal, the

118 decreased velocity and increased water depth in this area led to the accumulation of sand and silt on the

119 bottom, with a minimum water depth of approximately $0.7 \mathrm{~m}$. Following the removal of the dam, the

120 ponded zone disappeared and the natural shallow water habitat was restored to its original state, with

121 faster-flowing water, a water depth of $10-30 \mathrm{~cm}$, a natural substrate dominated by stones and cobbles,

122 the original gradient (approx. 0.3\%) and the presence of water riffles, thus highly suitable brown trout

123 (S. trutta) spawning and nursing grounds. It is worth noting that this type of habitat is scarce in larger

124 Danish streams due to years of human alterations, making this location of particularly high interest.

A second location was surveyed from 1987 through to $2016,1.5 \mathrm{~km}$ downstream of the dam

126 (Figure 1, B). This stretch was recognized as excellent for spawning, even before the dam was

127 removed. The lake trout from Lake Moss $\emptyset$ gained easier access to this area after 1992, when a fish

128 ladder was built at a weir near the lake. Before 1992, the brown trout population was almost entirely

129 dependent on the spawning of resident brown trout.

130

131

Fish density: mark-and-recapture

132 In the fall, the upstream (from 1997 to 2016) and the downstream (from 1987 to 2016) locations were

133 surveyed for lengths of $160 \mathrm{~m}$ and $600 \mathrm{~m}$, respectively. The width of the river at these locations was

134 approximately $20 \mathrm{~m}$. Each location was electrofished once using two electrodes, with all captured

135 brown trout marked (fin-clipped in this case). The following day, the same locations were electrofished

136 a second time. All previously marked fish (i.e., recaptures) and unmarked fish (i.e., new captures) were

137 counted. The numbers were then used to calculate fish density estimates. Fish below $14 \mathrm{~cm}$ were

138 considered young of the year (YOY) while larger fish (above $14 \mathrm{~cm}$ ) were pooled together and 
considered older fish (OLD). The two groups were distinguishable due to a bimodal length distribution.

140 The following formula was applied to calculate density estimates of brown trout:

141

$$
N=\frac{(M+1)(C+1)}{R+1}
$$

142 Where, $\mathrm{N}$ is the density estimate, $\mathrm{M}$ is the number of fish caught and marked during the first sampling,

$143 \mathrm{C}$ is the total number of captured fish during the second sampling (including recaptures), and $\mathrm{R}$ is the

number of recaptures during the second sampling (Lockwood and Schneider 2000). Results are

145 presented as number of fish per meter (length) of river, in accordance to the national Danish Brown

146 Trout Index (Kristensen et. al 2014), which states that population estimates of YOY in Danish streams

147 wider than $2 \mathrm{~m}$ should not be calculated as number per $\mathrm{m}^{2}$ as YOY mainly inhabit the river banks.

Statistical analyses

150 Mann-Whitney U-tests were used to compare trout density before and following removal of the Vilholt dam. The density (fish per m) of yearling (YOY) and older (OLD) fish were analyzed separately in both the upstream (A) and downstream (B) zones. The analyses were done using R 3.1.2 (R Core Team, 2014). Variation in association with recorded mean values is given as standard deviation $( \pm \mathrm{SD})$ 154 throughout.

\section{Results}

157 An immediate increase of YOY brown trout was observed at the upstream stretch after removal of the 158 dam, followed by a downstream increase in YOY after three years. In the upstream zone, mean YOY 159 density was $0.03 \pm 0.04$ fish per $m$ before removal of the dam and $6.21 \pm 2.77$ fish per m following dam 160 removal. The mean upstream OLD density before removal was $0.16 \pm 0.08$ fish per $\mathrm{m}$, and $0.30 \pm 0.07$ 
161 fish per $\mathrm{m}$ following removal. The mean downstream YOY density before and following the dam 162 removal was $1.2 \pm 0.99$ and $6.2 \pm 2.8$ fish per m, respectively. For OLD fish, the mean downstream 163 density was $0.31 \pm 0.16$ fish per $\mathrm{m}$ before dam removal and $0.43 \pm 0.21$ fish per $\mathrm{m}$ following dam 164 removal.

In the upstream zone, both YOY $(U=24.0, p=0.019)$ and OLD fish $(U=22.5, p=0.041)$

166 densities increased significantly following dam removal (Figure 2A, 3A). In the downstream zone, 167 YOY density increased significantly following dam removal ( $\mathrm{U}=62, \mathrm{p}<0.001$, Figure $2 \mathrm{~B}, 3 \mathrm{~A})$, but no 168 significant change in OLD density was found $(\mathrm{U}=46, \mathrm{p}=0.14$; Figure $2 \mathrm{~B}, 3 \mathrm{~B})$.

\section{Discussion}

171 The EU Water Framework Directive states that a watershed with a "good" ecological status should 172 have biological elements that show little distortion as a result of anthropogenic activities, though the 173 quality of these elements may deviate slightly from those observed in undisturbed conditions. A "high" 174 ecological status requires that a system suffer no or very minor anthropogenic disturbances, with 175 biological elements completely unaffected (Directive 2000/60/EC of the European Parliament and of 176 the Council, 2000). Simultaneously, the European Renewable Electricity Directive (2001/77/EC) 177 encourages the use of small-scale hydropower facilities to generate renewable energy. The presence of 178 dams (both small and large), and their associated environmental and biological impacts to freshwater 179 ecosystems, precludes an ecologically good status, as defined by the framework. The difficulty of 180 achieving this status is further exacerbated by the encouragement of the directive to establish small 181 hydrodams, making management and recovery plans contradictory and almost unachievable. Similar 182 contradictive directives exist at the international level (e.g., Sustainable Development Goals by United 183 Nations). 
The availability and access to suitable habitats is of crucial importance for a wide range of freshwater species, whether during spawning migration, feeding or refuge seeking (Northcote 1984; Taylor et al. 1993; Lucas and Baras 2001). The observed increase in YOY density both upstream and downstream of where the Vilholt dam was located, along with the upstream increase in OLD fish, suggests that (1) the natural habitat quality was restored in the ponded zone as a highly suitable spawning and nursing habitats, (2) safe passage and access to highly suitable spawning habitat upstream was reestablished, and (3) movement between the two spawning grounds increased recruitment. Here, we demonstrate that restoring river connectivity has allowed for a huge number of fish to be born and thrive in an area previously devoid of YOY fish, presumably due to restored spawning habitat and the ease of access to these high quality spawning grounds. The recorded density of YOY trout in the present study (mean=6.2 YOY/m on both stretches) place the river in "good ecological status" according to the EU Water Framework Directives (the Danish threshold is 2.5 YOY/m) and is in fact greater than normally observed in large Danish rivers, suggesting that barrier removal may be the best mitigation approach in the context of river restoration in fragmented rivers. The removal of the Vilholt dam restored the naturally adequate trout habitat in the former ponded zone, resulting in an immediate increase in both YOY and OLD fish upstream in 2009. This is likely because the removal allowed for the upstream passage of spawners from the lake, along with providing highly suitable habitat for young fish to thrive, thus increasing survival. The removal had little physical effect on the downstream habitat, which was already suitable for spawning. We note that beginning in 1992, an increase in OLD fish was observed downstream. This is due to the establishment of a fish ladder at a dam located between Vilholt and Lake Moss $\varnothing$. This fishpass led to a larger YOY density in 1993. We also note that a sudden decrease in fish was observed in 1994; a large storm caused the dam to break down, letting large amounts of mud and silt to be flushed downstream, practically 
207 eliminating the year class. The year following removal (2009), neither YOY nor OLD fish densities 208 increased downstream of the dam. In 2011, a large increase in YOY individuals downstream was 209 observed. The large increase in YOY upstream in 2009 would have yielded a large smolt cohort (length $21012-15 \mathrm{~cm}$ ) which likely migrated down to Lake Moss $\varnothing$. These individuals would then be returning to 211 spawn in both stretches in winter 2010-2011, likely contributing to the large YOY density observed in 2122011 both upstream and downstream of the former dam. Furthermore, it is also possible that YOY from 213 upstream moved downstream to find suitable habitat if the density of fish is too high upstream.

We have shown that barrier removal can be beneficial for fish density especially upstream, but also downstream. Since the removal, local anglers have also noticed an increase in the size and number of lake trout caught in Lake Mossø. While these observations suggest that the removal of an artificial obstacle may be beneficial at a whole-system level, we cannot make that conclusion for certain as our study did not specifically evaluate this. While the Gudenaa river system supports a sustainable population of older fish, including returning lake trout spawners from Lake Moss $\varnothing$ as well as resident trout, a wide spatial distribution of spawning and recruitment is needed to maintain population levels over time (Berkeley et al. 2011). Before the Vilholt dam was removed, the rate of spawning was low, with few YOY surviving in the ponded zone. YOY are an important component for maintaining population sustainability, and barriers may truncate the age-structure and the range of distribution of fish species, with potentially devastating effects on population sustainability. case) can affect the density and distribution of river spawning fish. Low-head barriers of this type, which can obviously lead to the deterioration of natural spawning and nursery areas in ponded zones, are rarely considered in management plans. It is our hope that these results will reinforce the need to firstly, include smaller weirs and dams in management plans, and secondly, considered removal as an 
option rather than immediately attempt to establish artificial fish passage. Our findings have important

231 implications for the management of barriers across the world. Environmental directives from many

232 agencies (e.g., EU Waterframe Directive, UN Sustainable Development Goals) have made

233 contradicting requests, with emphasis on reducing pollution, but little to no demands made to improve

234 ecosystems impacted by barriers. Given the immediate positive effects of the removal of small barriers, 235 this approach should be viewed as an economically and ecologically profitable option.

236

237 Authors' Contributions

238 KBG participated in the data analysis, data interpretation, manuscript conception and revision. JN

239 participated in the data acquisition and interpretation, as well as manuscript revision. KA and MHL

240 participated in data interpretation and manuscript revision.

\section{Acknowledgments}

243 We are thankful to all the volunteers (including community members and anglers) who helped with the 244 electrofishing surveys through the years. Funding for this research was provided by the Danish Rod and 245 Net Fish License and the European Union AMBER (Adaptive Management of Barriers in European 246 Rivers) project.

\section{Data Accessibility}

249 Data will be deposited on figshare upon acceptance of the manuscript. 
252 Aarestrup, K., \& Jepsen, N. (1998). Spawning migration of sea trout (Salmo trutta (L)) in a Danish 253 river. Hydrobiologia, 371, 275-281.

254

255

256

257

258

259

260

261

262

263

264

265

266

267

268

269

270

271

272

273

274

Aarestrup, K., \& Koed, A. (2003). Survival of migrating sea trout (Salmo trutta) and Atlantic salmon (Salmo salar) smolts negotiating weirs in small Danish rivers. Ecology of Freshwater Fish, 12(3), 169-176.

Baxter, R.M. (1977). Environmental effects of dams and impoundments. Annual Review of Ecology and Systematics, 8(1), 255-283.

Bednarek, A. T. (2001). Undamming rivers: a review of the ecological impacts of dam removal. Environmental management, 27(6), 803-814.

Berkeley, S. A., Hixon, M. A., Larson, R. J., \& Love, M. S. (2004). Fisheries sustainability via protection of age structure and spatial distribution of fish populations. Fisheries, 29(8), 23-32.

Birnie-Gauvin, K., Aarestrup, K., Riis, T.M.O., Jepsen, N., Koed, A. (in press). Shining the light on the loss of rheophilic fish habitat in lowland rivers as a forgotten consequence of barriers and its implications for management. Aquatic Conservation: Marine and Freshwater Ecosystems. doi: 10.1002/aqc. 2795

Bunn, S. E., \& Arthington, A. H. (2002). Basic principles and ecological consequences of altered flow regimes for aquatic biodiversity. Environmental management, 30(4), 492-507.

Burroughs, B. A., Hayes, D. B., Klomp, K. D., Hansen, J. F., \& Mistak, J. (2010). The effects of the Stronach Dam removal on fish in the Pine River, Manistee County, Michigan. Transactions of the American Fisheries Society, 139, 1595-1613.

Catalano, M. J., Bozek, M. A., \& Pellett, T. D. (2007). Effects of dam removal on fish assemblage structure and spatial distributions in the Baraboo River, Wisconsin. North American Journal of Fisheries Management, 27, 519-530. 
275 Cooke, S. J., Bunt, C. M., Hamilton, S. J., Jennings, C. A., Pearson, M. P., Cooperman, M. S., \& 276 Markle, D. F. (2005). Threats, conservation strategies, and prognosis for suckers

277

278

279

280

281

282

283

284

285

286

287

288

289

290

291

292

293

294

295

296 (Catostomidae) in North America: insights from regional case studies of a diverse family of non-game fishes. Biological Conservation, 121(3), 317-331

Cowx, I. G., \& Welcomme, R. L. (1998). Rehabilitation of rivers for fish. Food \& Agriculture Organization of the United Nations. Oxford: Fishing News Books.

Downward, S., \& Skinner, K. (2005). Working rivers: the geomorphological legacy of English freshwater mills. Area, 37, 138-147.

Doyle, M. W., Stanley, E. H., Harbor, J. M., \& Grant, G. S. (2003). Dam removal in the United States: emerging needs for science and policy. Eos, Transactions American Geophysical Union, 84, 2933.

Doyle, M. W., Stanley, E. H., Orr, C. H., Selle, A. R., Sethi, S. A., \& Harbor, J. M. (2005). Stream ecosystem response to small dam removal: lessons from the Heartland. Geomorphology, 71, 227-244.

Dudgeon, D. (1992). Endangered ecosystems: a review of the conservation status of tropical Asian rivers. Hydrobiologia, 248(3), 167-191.

Hall, J. W., Smith, T. I., \& Lamprecht, S. D. (1991). Movements and habitats of shortnose sturgeon, Acipenser brevirostrum in the Savannah River. Copeia, 695-702

Hitt, N. P., Eyler, S., \& Wofford, J. E. (2012). Dam removal increases American eel abundance in distant headwater streams. Transactions of the American Fisheries Society, 141, 1171-1179.

Jepsen, N., Aarestrup, K., Økland, F., \& Rasmussen, G. (1998). Survival of radio-tagged Atlantic salmon (Salmo salar L.) and trout (Salmo trutta L.) smolts passing a reservoir during seaward 
migration. In Advances in Invertebrates and Fish Telemetry (pp. 347-353). Springer Netherlands.

Jungwirth, M., Schmutz, S., \& Weiss, S. (Eds.). (1998). Fish migration and fish bypasses (Vol. 4). Oxford: Fishing News Books.

301

Jungwirth, M., Muhar, S., \& Schmutz, S. (2000). Fundamentals of fish ecological integrity and their relation to the extended serial discontinuity concept. In Assessing the Ecological Integrity of Running Waters (pp. 85-97). Springer Netherlands.

Koed, A., Jepsen, N., Aarestrup, K., \& Nielsen, C. (2002). Initial mortality of radio-tagged Atlantic salmon (Salmo salar L.) smolts following release downstream of a hydropower station. In: Aquatic Telemetry (pp. 31-37). Netherlands: Springer.

Kristensen, E.A., Jepsen, N., Nielsen, J., Pedersen, S., \& Koed A. (2014). Dansk Fiskeindeks For Vandløb (DFFV). Aarhus Universitet, DCE - Nationalt Center for Miljø og Energi, 58 s. Videnskabelig rapport fra DCE - Nationalt Center for Miljø og Energi nr. 95.

Lockwood, R.N. \& Schneider, J.C. (2000). Chapter 7: Stream fish population estimates by mark-andrecapture and depletion methods. In: Manual of Fisheries Survey Methods II: with periodic updates. Michigan Department of Natural Resources, Fisheries Special Report 25, Ann Arbor.

Lucas, M.C., \& Baras, E. (2001). Migration of freshwater fishes. John Wiley \& Sons.

Lucas, M.C., Bubb, D.H., Jang, M.H., Ha, K., \& Masters, J. E. (2009). Availability of and access to critical habitats in regulated rivers: effects of low-head barriers on threatened lampreys. Freshwater Biology, 54(3), 621-634.

McAllister, D.E., Hamilton, A.L., \& Harvey, B. (1997). Global freshwater biodiversity: striving for the integrity of freshwater systems. Sea Wind, 11, 1-40. 
Morita, K., \& Yamamoto, S. (2001). Contrasts in movement behavior of juvenile white-spotted charr between stocks above and below a dam. Fisheries science, 67(1), 179-181.

Northcote, T.G. (1984). Mechanisms of Fish Migration in Rivers. In: Mechanisms of Migration in Fishes (McCleave, J.D., Dodson, J.J., Neill, W.H. eds.). Plenum, NY, USA, pp 317-355.

Northcote, T.G. (1998). Migratory behaviour of fish and its significance to movement through riverine fish passage facilities. In: Fish migration and fish bypasses, Jungwirth, M., Schmutz, S. \& Weiss, S. (eds). Fishing News Books: Cambridge, 3-18. impacts on freshwaters in the Berlin-Brandenburg region. Die Erde, 142, 41-64.

Pess, G. R., McHenry, M. L., Beechie, T. J., \& Davies, J. (2008). Biological impacts of the Elwha

Nützmann, G., Wolter, C., Venohr, M., \& Pusch, P. (2011). Historical patterns of anthropogenic River dams and potential salmonid responses to dam removal. Northwest Science, 82, 72-90. River. Transactions of the American Fisheries Society, 120, 405-420. Statistical Computing, Vienna, Austria.

Ricciardi, A., \& Rasmussen, J.B. (1999). Extinction rates of North American freshwater fauna. Conservation Biology, 13, 1220-1222. 


\section{$342 \quad$ Figures}

343 Figure 1. The Vilholt dam was located in the Gudenaa river system, in central Jutland, Denmark, until

344 2008. The upstream and downstream sampling locations are represented by letters A and B,

345 respectively.

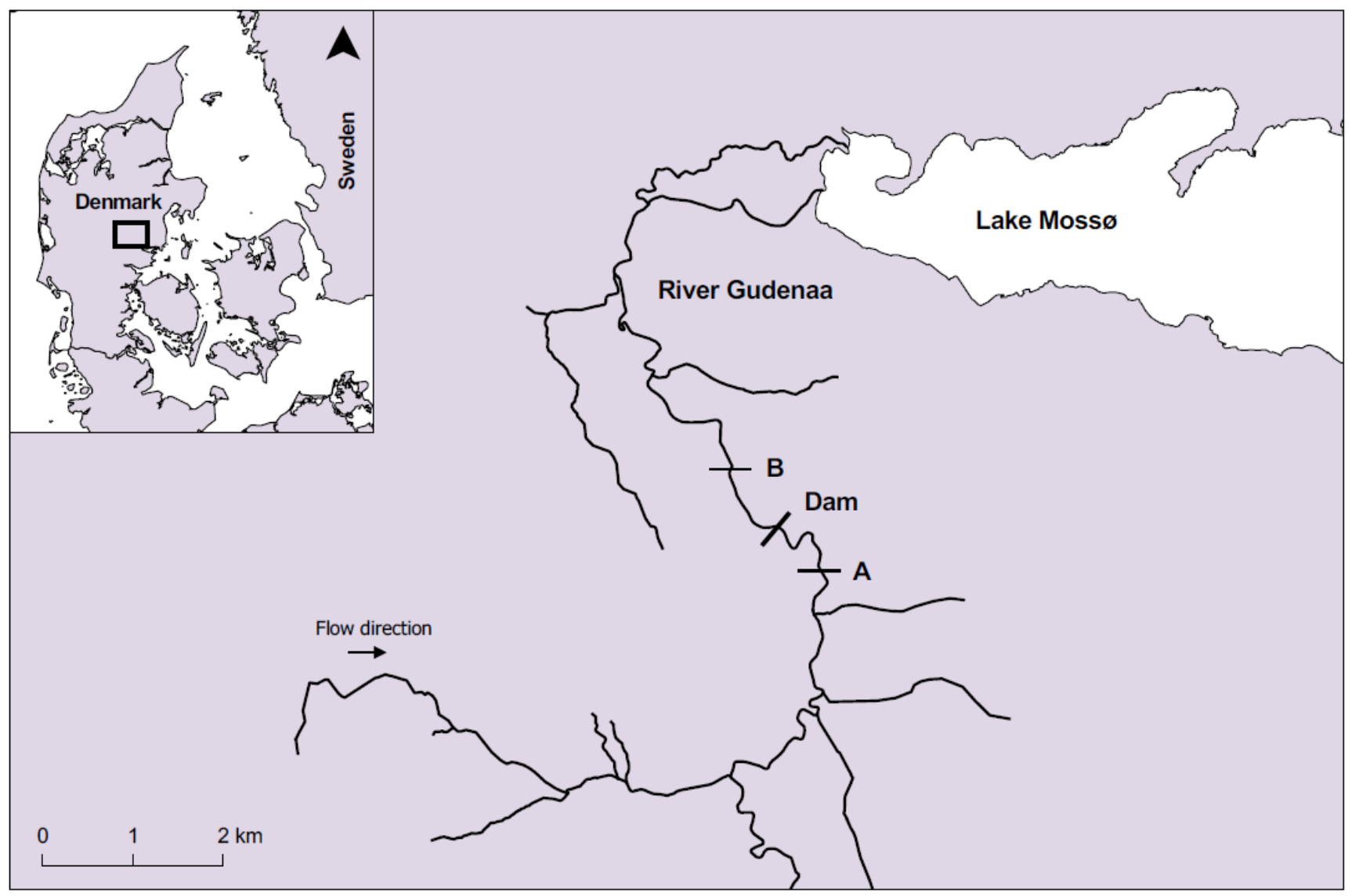


348 Figure 2. Brown trout (Salmo trutta) density number of individuals per $m$ of river) upstream (A) and 349 downstream (B) of the Vilholt dam. Downward pointing arrow shows dam removal. Asterisks 350 represent years when no surveys were carried out.

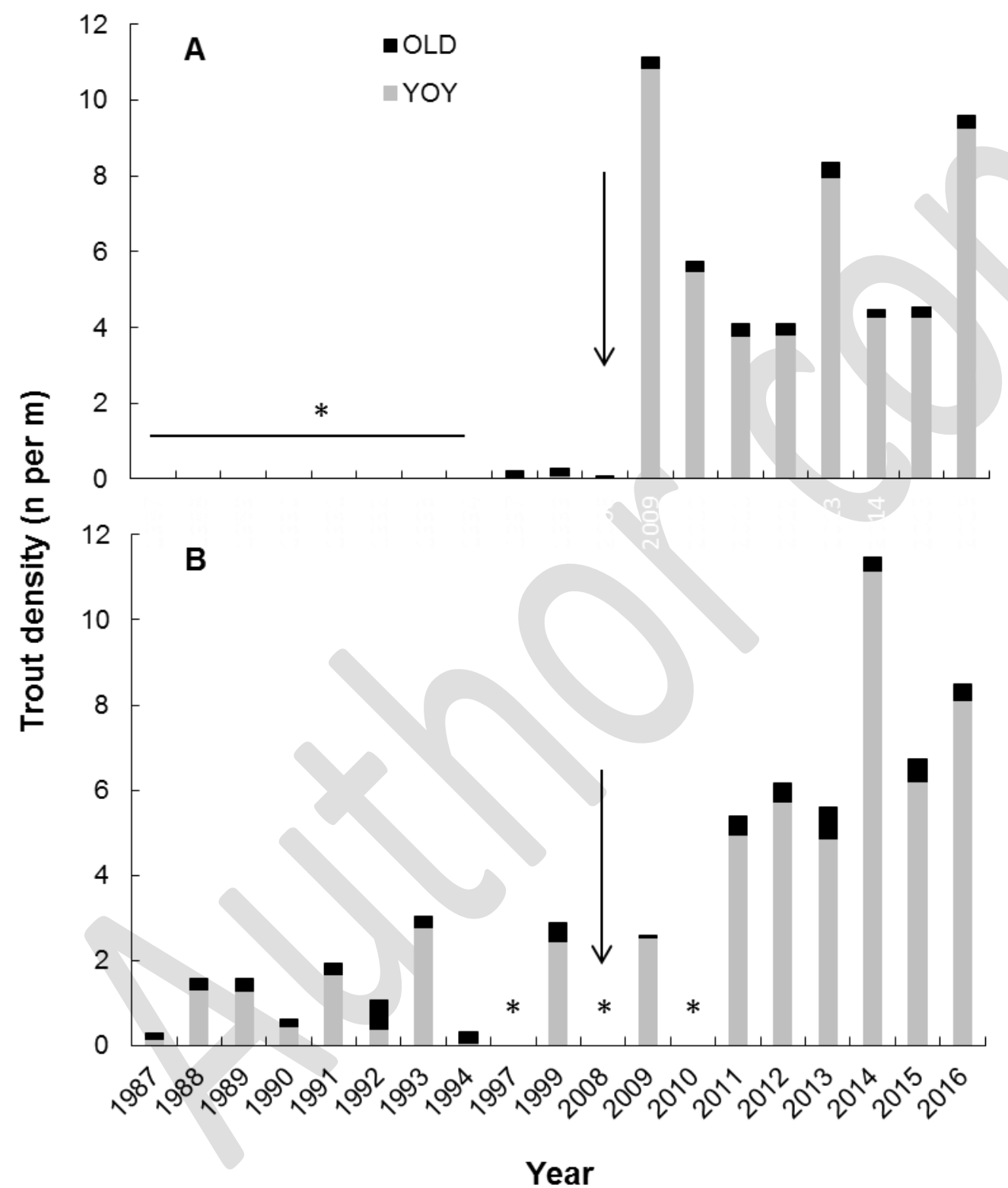


354 Figure 3. Boxplots showing the density of YOY (A) and OLD (B) trout (Salmo trutta) in the upstream 355 and downstream zones of the Vilholt dam before and after it was removed. The line within each box 356 represents median fish density, ends of boxes represent the 25th and 75th percentiles, and whiskers 357 represent the 10 th and 90 th percentiles. Asterisks indicate significant difference at $\mathrm{p}<0.05$. Note the 358 different scales on y-axes.
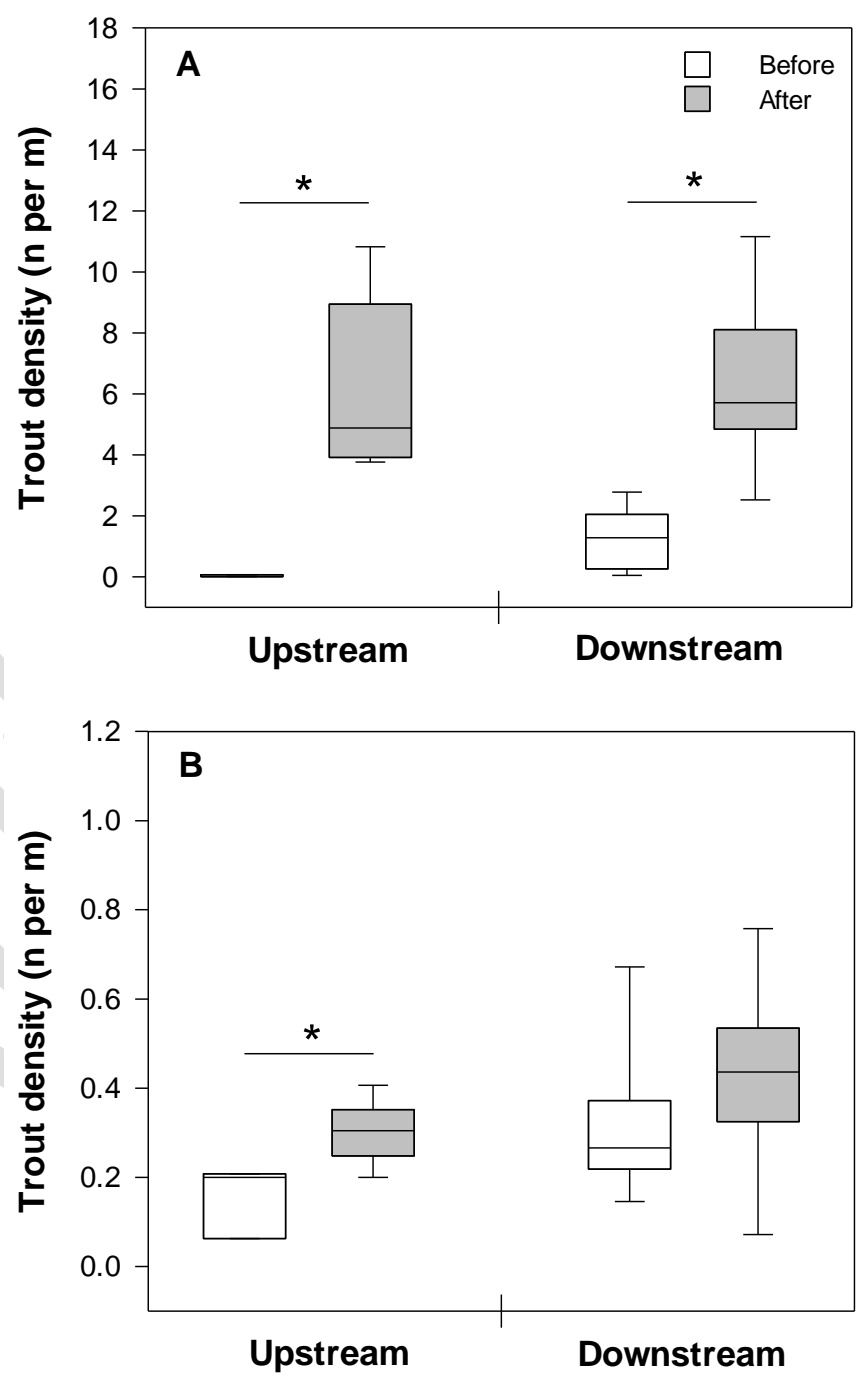